\title{
A Brief Introduction to Lu Xun and His Short Stories
}

\author{
GUO Yu \\ Leshan Normal University, Sichuan, China
}

\begin{abstract}
Lu Xun has been acclaimed Father of modern Chinese literature. He is the first writer to use the vernacular to write fiction. His short stories have laid a solid foundation for the development of modern Chinese fiction. Call to Arms (1923) and Wandering (1926) represent the greatest achievement of Chinese fiction creation at that time. His short stories are not only profound in thinking, but also worthy of admiration for their great value and innovation in art. Besides, there are abundant heavily Chinese culture-bound images in his stories, which are of great significance in cross-cultural communication.
\end{abstract}

Keywords: Lu Xun's short stories, modern Chinese literature, Call to Arms, Wandering

\section{Introduction}

Lu Xun (1881-1936) has been acclaimed Father of modern Chinese literature. He is the first writer to use the vernacular to write fiction. In his short stories, he exposes the crimes of feudalism and describes the plight of the peasants, who have been economically exploited and spiritually enslaved. He also depicts the fate of the intellectuals who struggle in the intense social contradictions. His fiction has laid a solid foundation for the development of modern Chinese fiction. There are totally 33 stories in Lu Xun's works, most of which are short stories. Call to Arms 呐喊 is comprised of 14 stories, written between 1918 and 1922. Lu Xun chose the title in order to boost the morale of the revolutionaries, urging them to go forward without the slightest fear. The stories show the tendency of anti-feudalism. Both in the general thrust and specific descriptions, they are in complete harmony with the May Fourth Spirit. In short, they embody the characteristics of the cultural and ideological revolution going on at the time. Wandering 彷得 composes 11 stories, written between 1924 and 1925. All of them focus on the sufferings and struggles of both women and intellectuals, and also reflect the change of the writer's thought. The book gives voice to a more profound and complicated feeling of the author. As Lu Xun says, some stories in Wandering are "more mature in skill and more profound in delineation", but "deficient in zeal" (Wang, 1984, p. 166). These two collections of Lu Xun's stories represent the greatest achievement of Chinese fiction creation at that time.

\section{Lu Xun and His Works}

Lu Xun (or Lu Hsun), the pen-name of Zhou shuren (周树人), alias Zhou Yucai (周豫才), was born into a declining literati family in Shaoxing, Zhejiang Province. He is a great man of letters, social thinker, the most important representative of contemporary Chinese literature, as well as one of the giants of the 20th century world literature. The pseudonym Lu Xun, derived by prefixing his mother's family name to Xun, was used for the first time when “A Madman's Diary” 狂人日记 was published in New Youth (or La Jeunesse, 新青年) in

Guo Yu, master, lecturer, School of Foreign Languages, Leshan Normal University, Sichuan, China. 
1918.

In Lu Xun's early life, there are two decisive and fundamental changes: One is his determination to study medicine in Japan instead of other popular subjects, such as law or politics among overseas Chinese students; and the other is that he gave up medicine to devote himself to literature, which became his career for a lifetime. During that period, Lu Xun was especially influenced by Friedrich Wilhelm Nietzsche (1844-1900) and Arthur Schopenhauer (1788-1860). Of all the writers he read about, he had a particular liking for the Russian writer Nicolai Gogol (1809-1852), whose works made a deep impression on his mind, in particular, Dead Souls, the Government Inspector, and the Diary of a Madman. Lu's respect and liking also went to Anton Chekhov (1860-1904), Petōfi Sándor (1823-1849), George Byron (1788-1824), Percy Shelly (1792-1822), Johann Wolfgang von Goethe (1749-1832), and Heinrich Heine (1797-1856). By reading and introducing these poets and writers, Lu Xun expresses his yearning to win independence and freedom for his people and his country, and his grave concern over the unawakened state of the people of his time.

At the end of the year of 1909 when he returned to China, Lu Xun finished his first short story “Reminiscences of the Past" 怀旧 in classical prose, though it was not published until 1913 when his brother sent it to the Short Story Magazine 小说月报. It dealt with the theme一the ignorance of the people in regard to the revolution-which he was to use in several of his stories and to develop furthest in "The True Story of Ah Q". Its first English version was "Looking Back to the Past" by Feng Yu-sing, published in T'ien Hsia Monthly in $1938^{1}$. Lu Xun passed away in Shanghai in the year of 1936. He was thought highly of as "the embodiment of the noble qualities of the Chinese people: undauntedness in face of the utmost danger and readiness to step forward bravely in dire moments" (Tang, 1993, p. 82).

Generally speaking, Lu Xun's published writings may be divided into four groups. The first group is fiction and prose, i.e., Call to Arms, Wandering, Old Tales Retold 故事新编, Wild Grass 野草 (1927), and Dawn Blossoms Plucked at Dusk 朝花夕拾 (1928). The second group is his miscellaneous writings, or essays, such as Hot Air 热风 (1925), Bad Luck 华盖集 (1926), Bad Luck (II) 华盖集续 (1927), The Grave 坟 (1927), Mixed Dialects 南腔北调集 (1934), and Essays of Qiejieting (I, II, III) 且介亭集 (1937). In the third group are found his studies on Chinese literature, for instance, A Brief History of Chinese Fiction 中国小说史 略 (1923). The last group is made up of 32 volumes of translations, such as Stories from Other Lands 域外小 说集 (1909).

\section{Literary Achievements \& Great Influence}

Lu Xun has created almost all the new forms for Chinese new literature, and enjoys the most prominent status in the Chinese literary development in the 20th century. His writings reflect the great achievements of the literary reform since the May Fourth Movement. His works cover almost every aspect of literary genres, ranging from stories to prose, from poems to essays, and from literary criticism to literary history. $\mathrm{He}$ is a master of style. His language is precise and his vocabulary is rich. He observed closely the language used by ordinary people and refined it for his works. He also advocated the proper adoption of foreign grammar and, if necessary, the use of classical Chinese. Thus, he sometimes used parallel sentences and symmetrical phrases so as to add variety and strength to his style. It must be pointed out that the basic language he prefers to is the vernacular, which has been refined by him so as to be concise and forceful.

${ }^{1}$ See T'ien Hsia Monthly, Vol. 6, No. 2, pp. 148-159, Feb., 1938. 
Above all, $\mathrm{Lu}$ Xun is the first writer to use the vernacular to write fiction. In addition to the content, he also reforms, in an artistic way, the traditional way of Chinese fiction writing. Moreover, with the prerequisite of "writing for the sake of human life", he has formed his unique aesthetic characteristic with a perfect combination of realism, romanticism, and symbolism. Secondly, essays occupy an extremely important place in Lu Xun's works. Particularly in the later period of his writing career, he was dedicated his time and energy to the writing of essays, for it is a sharp instrument in his anatomy of society and a powerful weapon in his attack on the enemy. In fact, Lu Xun's essays are full of the inextinguishable fire of anti-imperialism and anti-feudalism. His method remains the same throughout: "frivolous talk masking the treatment of serious matters, trivial talk conveying profound thoughts” (Tang, 1993, p. 120). Thirdly, Lu Xun's prose works are also of significance in his writings. "In the history of modern Chinese literature, Lu Xun's Wild Grass is the work which sets the trend for the writing of prose poems" (Tang, 1993, p. 131). And they show the foreign literary influence on form and style. "Reminiscences and thoughts, satire and lyrical expression of personal feelings—-they blend well in the writing" (Tang, 1993, p. 133). Fourthly, Lu Xun's study of Chinese literary history is also original and contributing. Chi-chen Wang once expressed his opinion about A Brief History of Modern Chinese Fiction as follows:

Important as it is, the History must be regarded as only a fragment in a larger scheme-a general history of Chinese literature that would take into consideration the social, economic and political background, a history that would be more that a mere series of eulogistic and anecdotal biographies of Literary figures as most histories of Chinese literature. (Wang, 1939, p. 115)

A fighter throughout his life, $\mathrm{Lu}$ Xun is "the most influential writer throughout the May Fourth Movement" (Tang, 1993, p. 87). He has achieved an unparalleled status in modern Chinese literary history with his prominent works of various genres as well as his devotion to creative work in various areas of literature and art. What he wrote has provided examples and standards for each period. "In the history of modern Chinese literature, his works are literary pointers" (Tang, 1993, p. 139).

\section{Call to Arms}

Call to Arms was published by Xinchao Press in August 1923 in its Literary Series, including 14 stories written between April 1918 and November 1922, which are: "A Madman's Diary", "Kung I-chi”, "Medicine”, "Tomorrow", "An Incident", "The Story of Hair", "Storm in a Teacup", "My Old Home”, "The True Story of Ah Q", "Dragonboat Festival”, "The White Light", "Some Rabbits and a Cat", "A Comedy of Ducks", as well as "Village Opera". This collection vividly depicts the actualities in old China's countryside and towns during the period from 1911 Revolution to the May Fourth Movement. Lu Xun's realistic description of peasant's life is beyond doubt originated from his early acquaintance and association with countrymen in his mother's hometown. In the preface, $\mathrm{Lu}$ Xun told where the stories came from:

When I was young I had many dreams. Most of them are now forgotten, but I see nothing in this to regret... However, my trouble is that I cannot forget completely, and these stories have resulted from what I have been unable to forget. (H. Y. Yang \& G. Yang, 1954, p. 9)

Prominent among all his stories is "The True Story of Ah Q". It is Lu Xun's longest and most important fiction work, undisputed masterpiece, as well as a great achievement of Chinese modern fiction. In this famous story, Lu Xun portrays the image of $\mathrm{Ah} \mathrm{Q}$, a poverty-stricken farmhand in the countryside, criticizes the failure 
of the 1911 Revolution, and reveals the social and historical origins of Ah Q and his defeatist habit of deceiving himself with the thought that he has won a moral victory whenever he is defeated. Unable to cope with the present, Ah Q flees into fantasies of a past in which his ancestors were rich and powerful or escapes into a future in which his unborn children will be. He has been seriously poisoned by the ideology of the feudal ruling class, as is shown by his most marked mental characteristic-the "psychological victory"-whenever he is defeated. The author was not in the least concerned with attacking certain individuals, but with denouncing the old society in its entirety. Actually, Lu Xun was portraying the silent soul of the Chinese nation and the life in old China that he had seen with his own eyes. What he described was the changes in the countryside and the tragic fate of the peasants around the 1911 Revolution.

According to his method of writing, he does not choose "definite models" for his characters, but creates them "out of all that he has seen" (H. Y. Yang \& G. Yang, 1980, p. 162). He has incorporated and generalized the words and deeds of other models as well as given artistic treatment in crating the complex typical character of Ah Q in the story. Once he was created, Ah Q has assumed a life of his own, often being taken for symbol of people who lack the courage to face facts. Lu Xun is a true representative of the voiceless, brutalized masses of China, and as such he takes his place in world literature. Chi-chen Wang once said,

In Ah Q, Lusin found the answer to questions that he had asked twenty years earlier. Ah Q is the only character out of contemporary Chinese fiction that actually lives in the minds of people and "Ah Q logic" the only phrase that has become a part of the Chinese vocabulary. With $A h Q$, Lusin was firmly established as the first and so far the only writer who had justified the literary revolution by his work. (Wang, 1939, p. 114)

Needless to say, such a typical character can live and move only in the society where "the strong bully the weak and the weak fawn over the strong", and where "power, money, prestige, and position in the hierarchy are all-important" while "love and compassion count for nothing" (Lyell, 1990, p. 37).

There is no any short story can, except "The True Story of Ah Q", in the history of Chinese literature, either reflect the real life and sculpture the typical character, to greatest extent, or arouse such tremendous responses in and exert such great influence upon the society. Lu Xun has made incomparable contribution in that he brings forward and probes into, for the first time, the issue of peasants in the history of Chinese literature. Besides, by setting the story against the background of the 1911 Revolution, Lu Xun "showed an unusual gift in his singular ability to see clearly and to articulate succinctly what others had only suspected or dimly perceived" (Lyell, 1990, p. 37).

A great thinker, Lu Xun has made a double criticism through the unforgettable artistic image of Ah Q. On the one hand, he keenly regrets and deeply criticizes the peasants' own failings, the result of serious feudal oppression and exploitation. He is especially aware of the defeatist "mental victory", which involves deceiving oneself and others as well as self-abasement. On the other hand, the author also relentlessly exposes and criticizes the poisonous ideology forced upon the oppressed people by the feudal ruling class. In this outstanding realistic story, Lu Xun has deeply reflected the tragic life of the working people in old China and their humiliated and benumbed life under the thousands of years of feudal oppression and a century of imperialist oppression. Lu Xun's only one work to employ the diction and structure of traditional Chinese popular fiction, "The True Story of Ah Q" ends on a dissonant note, which is also in accordance with the grim realities of life in the feudal society, where a criminal on his way to be executed had the right to shout out his innocence. 
The story is deeply enlightening. Its publication is a highly significant event in the history of modern Chinese literature. Not only is it a milestone revealing a further achievement in new literature and a solid foundation for modern Chinese realistic literature, it is also a splendid step forward in the realm of world literature. According to William A. Lyell (1990), "such was the impact of the story that 'Ah Q-ism' and 'psychological victory' became staple terms of everyday conversation in China, and these terms are still occasionally used even today" (p. 37). Therefore, through the story, Lu Xun has not only established his status in the history of Chinese modern literature, but also gained international reputation, with Ah Q becoming one of the famous typical characters in the world literature. In fact, the image of $\mathrm{Ah} Q$ is famous for his universal and typical characters, such as self-conceit, following the winds and waves, attributing all the evils to women, bullying the weaker and fearing the stronger, and most of all, "psychological victory".

"A Madman's Diary", the first real modern short story-modern in content, structure, and language-in the Chinese literature, was written in April, 1918 and published in the New Youth in the same year. The story was a first in two ways: It was the first story in China written in the vernacular instead of the literary language incomprehensible to ordinary people; and the pen name Lu Xun was used for this story the first time in Zhou Shuren's life. With the purpose "to expose the root cause of the old society's illness" and "to draw attention to it" so that "it might be cured", "Lu Xun's serious approach and artistic excellence are noticeable throughout the story" (Tang, 1993, p. 95). Through the description of the madman in the story, Lu Xun exposes, for the first time, to full view the evils of the clan system and the ethical system of Chinese feudal society. By employing the technique of realistic generalization, he fully reveals the cannibalistic nature of the feudal social system and feudal ethics. Meanwhile, this realistic story also has a rich flavor of romanticism. It is necessary to point out that, according to the author himself, his story was influenced by the Russian satirist Nicolai Gogol, who had written a short story with the same title. But Lu Xun himself also admitted that it was his own story that "expressed greater concern and indignation than Gogol's story" (Wang, 1984, p. 101). The fact that he had never lost his faith in mankind was obviously shown at the end of the story: "Save the children". The influence of the story was far-reaching, for “a year and a half after it was published, appeared Wu Yu's (吴虞, 1871-1949) 'Cannibalism and Feudal Ethics' in the same magazine” (Tang, 1993, p. 97).

In the story "Kong Yiji", the author tried to attack on the incurable harm done to the intellectuals by the feudal examination system and also indirectly censure the kind of mentality that Kong Yiji represents. "Medicine" is a story about the tragedy of both the ignorant masses and the revolutionaries. Although the story is based on a feeling of gloom, the wreath on the revolutionary's grave near the end implies that it does "hold out some rays of hope" (H. Y. Yang \& G. Yang, 1980, p. 201). "Storm in a Teacup" begins with the description of a pleasant evening scene in the countryside. However, it is hinted that "the awakening of the peasants will not come about until they have been further enlightened" (Tang, 1993, p. 98). "My Old Home" depicts the impoverished peasantry. Although in a lyrical vein, the story focuses on the point that "one should challenge the present reality and believe in the future" (Tang, 1993, p. 99). As the writer puts in the end, "the earth had no roads to begin with, but when many men pass one way, a road is made” (H. Y. Yang \& G. Yang, 1960, p. 93).

\section{Wandering}

Wandering was published by the Beixin Bookstore three years later in 1926. All of 11 stories, written between February 1924 and November 1925, focus on the sufferings and struggles of both women and intellectuals. It did reflect the changes in Lu Xun's thinking and feelings during those days after the New Youth 
group broke up and its members went different ways while he felt greatly disappointed. His gloomy mood found its expression in his own words: "my fighting spirit had diminished considerably" and he himself "hoped that the future would be different" (H. Y. Yang \& G. Yang, 1980, p. 201). On the frontispiece of Wandering, he quoted the following two lines from Qu Yuan's poem $L i$ Sao 离骚 to express his own sentiments: “The Way stretches endless ahead, I shall search through heaven and earth” (路漫漫其修远兮, 吾将上下而求索).

In this collection, there are three stories concerning about women issue. "The New Year's Sacrifice" tells the fate of a hapless woman under the Confucian moral code, who is isolated and cut off from any help and sympathy, and could find no way out. Throughout her life, Xianglin's wife cannot free herself from four kinds of durance, that is, the four authorities in the feudal society—-politics, superstition, the clan, and the husband.

The deep meaning of the story also lies in the fact that not only Fourth Master Lu, but even, who is in same social position as Xianglin's Wife, and those who 'savored' her misfortunes have all been poisoned by feudal ideas and conventions. (Tang, 1993, p. 100)

In fact, "they inflict mental suffering and unknowingly contribute to the creation of this ordinary yet tragic drama in the old society" (Tang, 1993, p. 100). "Regret for the Past" is the only love story Lu Xun has ever written, brief but touching, in which the main characters are two intellectuals awakened by the impact of the May fourth new trend of thought. Zijun, the heroine who is especially concerned, proclaims: "I am my own mistress. None of them has any right to interfere with me" (H. Y. Yang \& G. Yang, 1980, 1954 p. 175). In "Divorce", readers are faced with the possibility of bringing about a divorce from the woman's side. Aigu, the main female character, seems to be stronger than any female characters written before.

Another focus of this collection is about new-type intellectuals from the May Fourth Movement with certain fairly high ideals, whose tragic lives result from their lack of a definite orientation for lives although they have complaints, grievances, and illusions. In "In the Wineshop", through depicting Lü Weifu's change from a quick-witted and bold radical to one who is indifferent to everything, the author criticizes the intellectuals who were at first active in the May Fourth period but later became dispirited. Later, in "The Misanthrope" and "Regret for the Past", the author runs into a state of deep gloom. The hatred of Wei Lianshu, the main character of the former, develops so extreme as to end in failure and death, which shows that an individual's unreasonable resistance to the old society may even lead him to the opposite direction and decadence. In the latter story, although the author is full of sympathy for the two lovers, he also criticizes them repeatedly for they divorced from the masses and the struggle in real life.

\section{Conclusion}

Lu Xun is regarded as Father of modern Chinese literature, whose writings reflect the great achievements of the literary reform since the May Fourth Movement, and enjoy the most prominent status in the Chinese literary development in the 20th century. He is not prolific in fiction creation, but his two collections of stories, Call to Arms and Wandering, have exerted great influence upon other writers at that time and afterwards. They are different in that the author focuses on different themes with differentiated feelings, while they still share something in common. The typical surroundings and characters are almost the same or similar kind, namely, Luzhen and Weizhuang, peasants or intellectuals. Furthermore, the central idea permeating both books is, as Lu Xun himself has repeatedly explained, to "use the form of short stories" to expose "the degeneration of the upper classes in society and the miseries of the lower classes" (Wang, 1984, p. 148). His vivid and powerful 
descriptions have strengthened the artistic effectiveness of the two books and aroused people's contempt and hatred of these vile things. In conclusion, Lu Xun's stories objectively reflect the decline of the feudal class and the miserable living of the peasants during the period from the failure of the 1911 Revolution to the eve of the May 30th Movement of 1925.

Since they were published, Lu Xun's stories have been translated into various languages all over the world, and enjoyed an international reputation, in particular, his representative work, "The True Story of Ah Q". Moreover, Lu Xun's stories are celebrated for his skillful use of irony, in which readers find contradictory statements made by the author. Lu Xun's stories are characterized with a great volume of highly Chinese culture-loaded messages, including traditional thought, traditional convention, local folk customs, Chinese names and appellations, as well as certain historical background. This is also a good way to make foreign readers know more about Chinese culture and traditions.

\section{References}

Cao, J. R. (2006). A critical bibliography of Lu Xun. Shanghai: Fudan University Press.

Ge, B. Q. (1981). The story of “The True Story of Ah Q: in Other Countries”. Beijing: People's Literature Publishing House.

Hsia, T. A. (2004). The gate of darkness: Studies on the Leftist Literary Movement in China. Seattle: University of Washington Press.

Lee, L. O. (Ed.). (1985). Lu Xun and his legacy. Berkeley: University of California Press.

Lee, L. O. (Ed.). (1987). Voices from the iron house: A study of Lu Xun. Bloomington: Indiana University Press.

Lu, Y. D., \& Tang, D. H. (1984). The first exploration on the originality of Lu Xun's stories. Changsha: Hunan People's Publishing House.

Lyell, W. A. (Trans.). (1990). Diary of a madman and other stories. Honolulu: University of Hawaii Press.

Qian, L. Q. (2003). A general analysis of Lu Xun's work. Beijing: Peking University Press.

Peng, B. (2001). The comparative structure of desperation and hope in Lu Xun's stories. Shanghai: Academia Press.

Shen, D. (1998). Literary stylistics and fictional translation. Beijing: Peking University Press.

Shen, D. (2001). Narratology and the stylistics of fiction. Beijing: Peking University Press.

Tang, T. (1993). History of modern Chinese literature. Beijing: Foreign Languages Press.

Wang, C. C. (1939). Lusin: A chronological record, 1881-1936. China Institute Bulletin, 3(4), 99-105.

Wang, C. C. (Trans.). (1941). Ah Q and others: Selected stories of Lusin. New York: Columbia University Press.

Wang, S. J. (1984). Lu Xun: A biography. Beijing: Foreign Languages Press.

Weiss, R. F. (1985). Lu Xun-A Chinese writer for all times. Beijing: New World Press.

Xia, Z. Q. (2005). A history of modern Chinese fiction. Shanghai: Fudan University Press.

Yang, H. Y., \& Yang, G. (Trans.). (1954). Selected stories of Lu Hsun. Peking: Foreign Languages Press.

Yang, H. Y., \& Yang, G. (Trans.). (1960). Selected stories of Lu Hsun. Peking: Foreign Languages Press.

Yang, H. Y., \& Yang, G. (Trans.). (1972). Selected stories of Lu Hsun. Peking: Foreign Languages Press.

Yang, H. Y., \& Yang, G. (Trans.). (1980). Selected works of Lu Xun. Peking: Foreign Languages Press.

Yan, J. Y. (2002). On Lu Xun's polyphonic fiction. Shanghai: Shanghai Educational Publishing House.

Zhang, X. F. (Ed.). (2005). A new edition of Lu Xun's stories. Beijing: Beijing University of Technology Press.

Zhang, Z. Y., \& Zhang, M. Y. (Eds.). (1981). A selected work of research articles on Lu Xun in six decades. Beijing: China Social Sciences Press.

Zhou, Z. R. (2002). Characters in Lu Xun's stories. Shijiazhuang: Hebei Educational Publishing House. 